\title{
Reconsidering the potential role of saline springs in the Paleoindian occupation of Sandy
} Springs, Adams County, Ohio

Corresponding author

Matthew P. Purtill

Email: mpurtill@bsu.edu

Ball State University

Applied Anthropology Laboratories

Department of Anthropology

Burkhardt Building, Room 314k

Ball State University

Muncie, Indiana - 47306

16

17

18 
Abstract:

The potential role of saline springs in Paleoindian settlement models has been espoused for over 50 years. An early example of this adaptive strategy was proposed in 1973 by Roger

Cunningham in his formative discussion of the Paleoindian Sandy Springs site in Adams County, Ohio. Cunningham argued that saline springs located among local sand dunes acted as a significant draw for migrating game animals and, subsequently, the Paleoindian hunters that pursued them. Despite being widely accepted and repeated in the literature, the claim of salineenriched groundwater at Sandy Springs has never been evaluated quantitatively. To assess the accuracy of Cunningham's claim, this study completed electrical conductivity and $\mathrm{pH}$ analysis of surface water and sediment samples within a 20-km radius of Sandy Springs. Testing failed to identify water samples $>320$ ppm total dissolved solids, a result far below established thresholds for brackish or brine classification. Underlying local bedrock geology also is not conducive for the presence of saline springs, and no mention of salt licks, commercial salt wells, or animal trails has been identified in the literature for Adams County, Ohio. Sediment samples from sand dunes locations previously argued to contain saline springs at Sandy Springs also failed to yield statistically different $\mathrm{pH}$ values than those from non-dune, alluvial contexts. Overall, the reported presence of saline springs at Sandy Springs could not be verified by geochemical data. Instead, it is suggested in this article that saline groundwater was not a principal factor in determining Paleoindian occupation of the site. Alternative explanations for site occupancy include the possible presence of rare resources associated with a sand prairie ecosystem and the potential that Sandy Springs was positioned along an early trail system connecting the Upper Ohio Valley with the Tennessee and Cumberland Valleys.
\end{abstract}

Keywords:

Electrical conductivity

27 Sandy Springs

28 Paleoindian

29 Saline Springs

30 Upper Ohio River Valley 


\section{Introduction}

In the inaugural 1973 issue of Archaeology of Eastern North America, Roger Cunningham was among the earliest to suggest that the location of natural saline springs was a significant draw for late Pleistocene herbivores and the Paleoindian hunters who pursued them in the Upper Ohio Valley (Cunningham, 1973:121; see also Rolingson, 1964:72). Cunningham referred to the proximity of Paleoindian artifacts, saline springs, and the remains of Pleistocene megafauna such as mammoth (Mammut americanus) and bison (Bison antiquus) at northern Kentucky sites such as Big Bone Lick and Upper and Lower Blue Licks (Hansen, 1983, 1995; Rolingson, 1964; Schultz et al., 1963) as evidence for this adaptive land-use strategy. As additional support for this pattern, Cunningham further discussed several newly discovered Upper Ohio Valley sites that he claimed yielded Paleoindian material in association with saline springs (Cunningham, 1973:120122). Since 1973, a purported correlation between saline waters and Paleoindian sites in the eastern U.S. has become widely accepted and embedded in the literature (e.g., Anderson \& Gilliam, 2000:44; Brown, 1999:115, 2010:395; Dincauze, 1993; Maggard \& Stackelbeck, 2008:154; O'Brien, 1996:446-451; Smith, 1990a:98-111, 1990b:244; Tankersley, 1996:28, 1998:14).

Most prominent among these "new" sites discussed by Cunningham was Sandy Springs in southeastern Adams County, Ohio (Figure 1). Based on amateur collector data, Cunningham characterized Sandy Springs as a dense concentration of Paleoindian material distributed among relict sand dunes and saline springs (Cunningham, 1973:122). In 1994, Mark Seeman and colleagues expanded upon Cunningham's description by offering various hypotheses concerning site age and function based on their own analysis of local artifact collections. Notable was the confirmation of at least 98 Paleoindian points from the site (Seeman et al., 1994:81). Repeated occupation throughout the Paleoindian period is suggested by an inventory of Clovis ${ }^{1}(n=14)$, Cumberland $(\mathrm{n}=15)$, and lanceolate $(\mathrm{n}=34)$ point styles. A high frequency of intact points implied to Seeman et al. (1994:81) that Sandy Springs was neither a primary tool production area nor multi-activity base camp, but instead reflected a series of temporary hunting-collecting stations.

In Seeman et al.'s 1994 article, Cunningham's earlier claim of saline water at Sandy Springs was repeated and a personal communication was cited suggesting that springs recharge "from clay seams among or immediately below the dunes" (Seeman et al., 1994:79). In the same passage, Seeman et al. refers to an early nineteenth century salt works across the Ohio River in Vanceburg, Kentucky, as further support of the claim of high water salinity in area streams. Finally, they cite historical reports of a natural ford on the Ohio River, just upriver from Sandy Springs, as a favorable crossing point for both humans and migrating game (Seeman et al., 1994:79; see also Seeman \& Prufer, 1982:157).

\footnotetext{
${ }^{1}$ In the original publication, Seeman et al., (1994:81) partitioned "Clovis" point taxon into Clovis and Gainey styles. Recent studies, however, have questioned the utility of the "Gainey" taxon suggesting it is not based on empirical or quantitative evidence (e.g., Eren et al., 2011; Eren and Desjardine, 2015:109-110). For this study, the Clovis $(n=2)$ and Gainey $(n=12)$ inventory was combined and labeled as Clovis.
} 


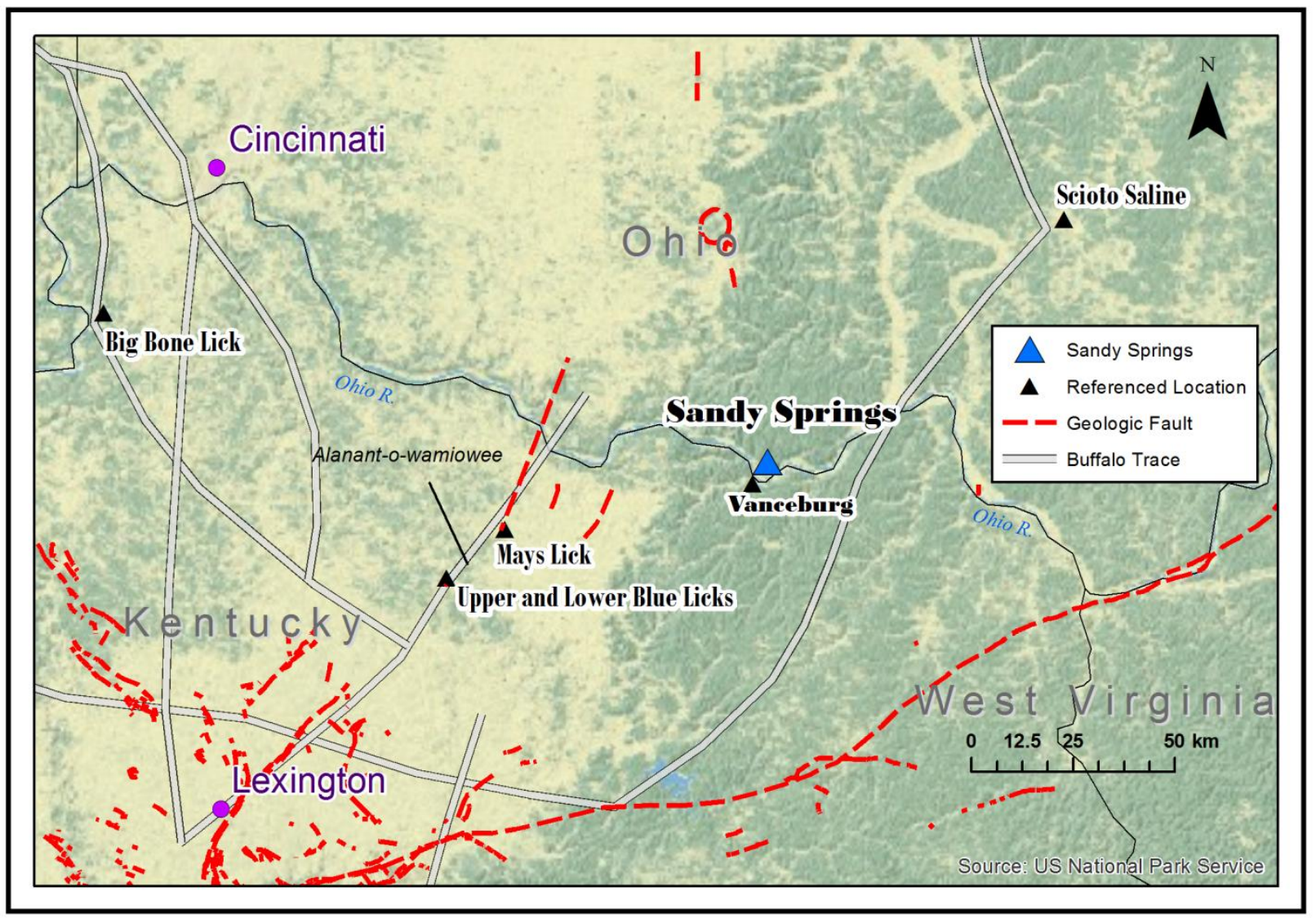

Figure 1. Geographic location of Sandy Springs Paleoindian site and locations referenced in text. Geologic fault locations based on Baranoski, 2013, and the Kentucky Geological Survey, 2016. Please note that a small geologic fault exists at the location of the Upper and Lower Blue Licks symbol. Buffalo trace locations based on Jakle 1969:690. 
The report of saline springs has played a significant role in Cunningham's, and later Seeman et al.'s, interpretation as to why Sandy Springs was occupied repeatedly during the Paleoindian Period. The presence of saline waters is thought to have attracted migrating game, especially herbivores, which could easily ford the Ohio River near Sandy Springs. Along the hummocky dune surface, it was suggested that Paleoindian hunters found excellent vistas of the surrounding landscape for game monitoring and topographic depressions in which hunters could seek concealment (Cunningham, 1973:120-122; Seeman et al., 1994:83-84). This elegant narrative, based largely on the supposition of saline springs, has important implications for many extant eastern U.S. Paleoindian adaptive land-use models, prey choice strategies, and mobility patterns (e.g., Anderson, 2013; Broster et al., 2013; Cannon \& Meltzer, 2004, 2008; Kelly \& Todd, 1988; Lepper \& Meltzer, 1991; Meltzer \& Smith, 1986; Smallwood, 2012; Surovell \& Waguespack, 2009; Tankersley, 1990; Waguespack \& Surovell, 2003). For example, this perspective posits Paleoindians at Sandy Springs as 'specialized hunters' (e.g., Kelly \& Todd, 1988:240; Tankerlsey, 1990) reducing risk by revisiting a landscape characterized by predictable, and abundant, animal resources. This incorporates components of both 'place-oriented' and 'technology oriented' strategies as the repeated reoccupation of Sandy Springs (place-oriented) is thought to have supported a specialized hunting lifestyle (technology-oriented). A similar argument has been made for the Paleoindian occupation of Sheridan Cave, Huron County, Ohio, where Redmond and Tankersley (2005:524) suggested periodic revisits to the sinkhole/cave to scavenge, or killed, entrapped animals.

The claim of saline waters at Sandy Springs largely has been accepted in the Paleoindian literature (e.g., Gramly \& Funk, 1990:16; Lepper, 1986:53; Lothrop \& Creemens, 2010:121; Smith, 1990a:244; Tune, 2016:311), despite the fact that ionic concentrations of local water sources have not been directly measured through gravimetric or conductivity means. The origin of Cunningham's initial claim is unclear but he cites an extended passage from Stout et al. (1932:11) on the importance and location of Ohio brines and highlights the fact that several local stream names are suggestive of hypersalinity such as Sulfur Creek and Long Lick Creek in Ohio and Salt Lick Creek in Kentucky (Cunningham, 1973:122). Close review of the Stout et al., passage, however, suggests that the authors only reference salt sources in eastern, not western, Ohio. Moreover, nowhere in their volume do the authors list Adams County, Ohio, as containing saline springs or commercial salt wells.

Given this ambiguity, the purpose of this research was to evaluate the long-held assumption that the Sandy Springs landscape contains natural saline waters of such concentration as to have attracted species pursued by late Pleistocene hunters. This study included review of relevant geological literature on potential saline groundwater sources and identification of historical passages that mention regional brackish waters or salt production, including information regarding the salt works noted at Vanceburg, Kentucky. Finally, electrical conductivity testing of surface water and sediment, and $\mathrm{pH}$ testing of sediment from dune and non-dune contexts, were used to assess the salinity of surface waters in the general Sandy Springs area. Electrical conductivity of surface waters from two renowned Ohio Valley saline springs, Big Bone Lick in Union, Kentucky (Tankersley, 1985, 1996, 2007; Tankersley et al., 2009), and the Scioto Saline in Jackson, Ohio (Hansen, 1983, 1995; Hildreth, 1838:57) (Figure 1), were tested and compared to Sandy Springs results. 


\section{Distribution and composition of saline springs in the eastern U.S.}

"Springs, in the form of seeps and rills and often saline, appear regularly among these high sand terraces and dunes and appear to have been important attractions for herbivores and thus for man who preyed upon them."

Roger Cunningham, 1973:120-121 (italics added)

Although Cunningham is correct in stating that fresh water springs are common, saline springs are rare in the eastern U.S. due to the humid climate and solubility of exposed evaporite beds (Phalen, 1919:14). The composition, concentration, and location of soluble salts in groundwater vary according to climate, bedrock geology, hydraulic conductivity and gradient, preferential flow paths, and ultimate saline source (Hillel, 1980:233-257; Todd \& Mays, 2005:329-333). When present in the eastern U.S., such springs typically result from dissolution of deep-seated evaporitic rocks rich in anhydrite $\left(\mathrm{CaSO}_{4}\right)$, gypsum $\left(\mathrm{CaSO}_{4} * 2 \mathrm{H}_{2} \mathrm{O}\right)$, and halite $(\mathrm{NaCl})$ minerals (Carlson, 1991:11). They are often associated with sedimentary environments where dense fluids and hydrocarbons tend to collect. A second potential saline source is connate waters trapped in deep, porous bedrock sections such as sandstones under high hydrostatic pressures and overlain by faulted bedrock. In such contexts, brines and saline solutions may discharge to the surface where they are subject to plant uptake, evaporation, and mineral precipitation as compounds such as gypsum $\left(\mathrm{CaSO}_{4} * 2 \mathrm{H}_{2} \mathrm{O}\right)$.

In some cases, saline water is enriched in sulfur concentrations, often marked by a bluish-white color and sulfur odor (e.g., $\mathrm{H}_{2} \mathrm{~S}$ ). Local bacterial reduction of sulfates (e.g., $\mathrm{SO}_{4}$ ) appears to characterize some springs (McCartney et al., 2005; see also Hem, 1985:116-117). Available water chemistry data on Ohio Valley brines derive from deep well samples where salinity is more concentrated due to variable-density flow paths and interaction between bedrock and fresh groundwater. Typical geochemical gradients include near-surface groundwater rich in bicarbonate anions with chloride-enriched waters occupying deeper sections (Todd \& Mays, 2005:330). Stout et al. (1932:15-18) report that deep well samples (>500 m) in eastern Ohio produce heavily concentrated brines containing values in the 170,000 to $240,000 \mathrm{ppm}$ total dissolved solids (TDS) range.

When discharged at the surface, saline springs were colloquially referred to as salt licks, or mineral licks, by early Euro-American settlers (Hansen, 1995:2; Jakle, 1969; Stout et al., 1932:15) due to the predilection of ungulates to "lick the earth on account of the saline particles with which it is impregnated" (Imlay, 1792:43). Consumption of salt, especially sodium-based compounds, is essential for various physiological functions in mammals from maintaining osmotic balance in body fluids to facilitating electrical conductivity between nerves (Dethier, 1977:744). The need for supplementary sodium, often on a seasonal basis, is especially prevalent in herbivores of eastern North America where foraged diets typically are sodium-poor (Botkin et al., 1973; Fraser \& Reardon, 1980:36; Hellgren \& Pitts, 1997; Weeks \& Kirkpatrick, 1976). Various strategies have been adapted by animals to supplement low-sodium diets such as the geophagous consumption of sodium-enriched soils found through seasonal migrations to saline springs or seeps (e.g., Kreulen, 1985). 
Numerous licks such as Big Bone Lick and Upper and Lower Blue Licks of northern Kentucky, Saltville in southwestern Virginia, and the Scioto Saline in eastern Ohio, appear to have been producing saline waters since at least the late Pleistocene based on the presence of fauna of extinct species including mastodon (Mammut americanus), muskox (Bootherium bombifrons), bison (Bison antiquus), and stag-moose (Cervalces scotti), among others (Boisvert, 1984; Hansen, 1995:1; Ray et al., 1967; Schultz et al., 1963; Tankersley et al., 2009). In the historic period, licks are known to have attracted seasonally migrating bison (Bison bison americanus) which resulted in the development of well-defined trails called buffalo traces (Jakle, 1969:691692; Wilcox, 1970) (see Figure 1).

\section{Sandy Springs Environmental Context}

Sandy Springs is located on a broad, $2.4 \mathrm{~km}$ wide meanderbelt of the Ohio River (Figure 2). Situated in the heavily dissected Shawnee-Mississippian Plateau of the Appalachian Plateaus province (Brockman, 2006), Sandy Springs is underlain by Silurian, Devonian, and Mississippian shales, limestones, siltstones, and thickly bedded sandstones. Three geomorphic surfaces (S1-S3) rise above a modern floodplain (S0). The S1 surface displays a pronounced ridge-and-swale topography and is interpreted as a Holocene alluvial landform correlative to those at Stuart Station, only 40 km downstream of Sandy Springs (Purtill, 2012:21-41). S2 and S3 surfaces have been interpreted as late Wisconsin outwash terraces (Morris \& Pierce, 1967; Pavey et al., 1999) and reportedly contain up to $45 \mathrm{~m}$ of well-sorted gravels, sands, silts, and clay.

The upper surfaces on both the Ohio and Kentucky sides of the river contain a $\sim 304$ ha dune field characterized by prominent relict sand dunes up to $18 \mathrm{~m}$ in height (Morris \& Pierce, 1967; Purtill \& Kite, 2015; Purtill, 2016). Springs have been reported to exist among these dunes (Cunningham 1973:121-122) and the author observed one active seep emerging from a sand sheet near U.S. 52. At Sandy Springs, dunes are droughty and support remnant sand prairie vegetation which may be fed by natural springs. The prairie, which likely was more extensive in range prior to agricultural disturbance, supports many xeric plant species including eastern prickly pear cactus (Opuntia humifusa), passion flower (Passiflora incarnata), spreading sandwort (Arenaria patula), little whitlow grass (Draba brachycarpa) and silkgrass (Chrysopis graminifolia) (Noelle \& Blackwell, 1972; Vincent, 2011).

\section{Materials and methods}

\subsection{Sample Locations}

A total of 16 surface water and 14 sediment samples were tested to characterize the potential for saline springs at Sandy Springs (Table 1; Figures 2 and 3). All but three (WS5, WS14, and WS15) derive from within $20 \mathrm{~km}$ of Sandy Springs. Water sample sources include McCall Run, Gilpen Run, Salt Lick Creek, Sulphur Creek, Upper Twin Creek, Turkey Creek, and an unnamed tributary. The active seep near U.S. 52 was sampled (WS10) and sediment samples were 


\begin{tabular}{|c|c|c|c|c|}
\hline Sample Site and Context & Code & Sample Type & Latitude & Longitude \\
\hline Unnamed tributary next to dunes & WS11 & Surface Water & 38.61516 & -83.29716 \\
\hline Sand sheet seep & WS10 & Surface Water & 38.61332 & -83.30007 \\
\hline McCall Run & WS4 & Surface Water & 38.60905 & -83.28635 \\
\hline Ohio River & WS9 & Surface Water & 38.60555 & -83.31338 \\
\hline Gilpen Run Creek & WS8 & Surface Water & 38.62823 & -83.30711 \\
\hline Salt Lick Creek & WS7 & Surface Water & 38.60262 & -83.32183 \\
\hline Sulphur Creek & WS1 & Surface Water & 38.63729 & -83.32289 \\
\hline Sulphur Creek & WS13 & Surface Water & 38.64218 & -83.32178 \\
\hline Ohio River & WS3 & Surface Water & 38.64081 & -83.33139 \\
\hline Salt Lick Creek & WS6 & Surface Water & 38.60111 & -83.34678 \\
\hline Upper Twin Creek & WS16 & Surface Water & 38.63331 & -83.25152 \\
\hline Sulphur Creek & WS12 & Surface Water & 38.65218 & -83.32134 \\
\hline Turkey Creek & WS2 & Surface Water & 38.69816 & -83.10456 \\
\hline Little Salt Creek & WS5 & Surface Water & 39.04706 & -82.63213 \\
\hline Salt spring, Big Bone Lick State Park & WS14 & Surface Water & 38.88643 & -84.75220 \\
\hline Big Bone Creek, Big Bone Lick State Park & WS15 & Surface Water & 38.88675 & -84.75250 \\
\hline Dune & $47,52,60,62$ & Sediment & 38.61378 & -83.29796 \\
\hline Sand Sheet & 4 & Sediment & 38.61294 & -83.29908 \\
\hline Sand sheet & 15 & Sediment & 38.61366 & -83.29931 \\
\hline Dune & 85 & Sediment & 38.61419 & -83.30052 \\
\hline Dune/Suspected Seep area & $141,142,144$ & Sediment & 38.61381 & -83.29768 \\
\hline Tributary Alluvium & 36,37 & Sediment & 38.61561 & -83.30053 \\
\hline Tributary Alluvium & 42,46 & Sediment & 38.61550 & -83.30088 \\
\hline
\end{tabular}

2 Table 1. Geographic location of sample sites. 


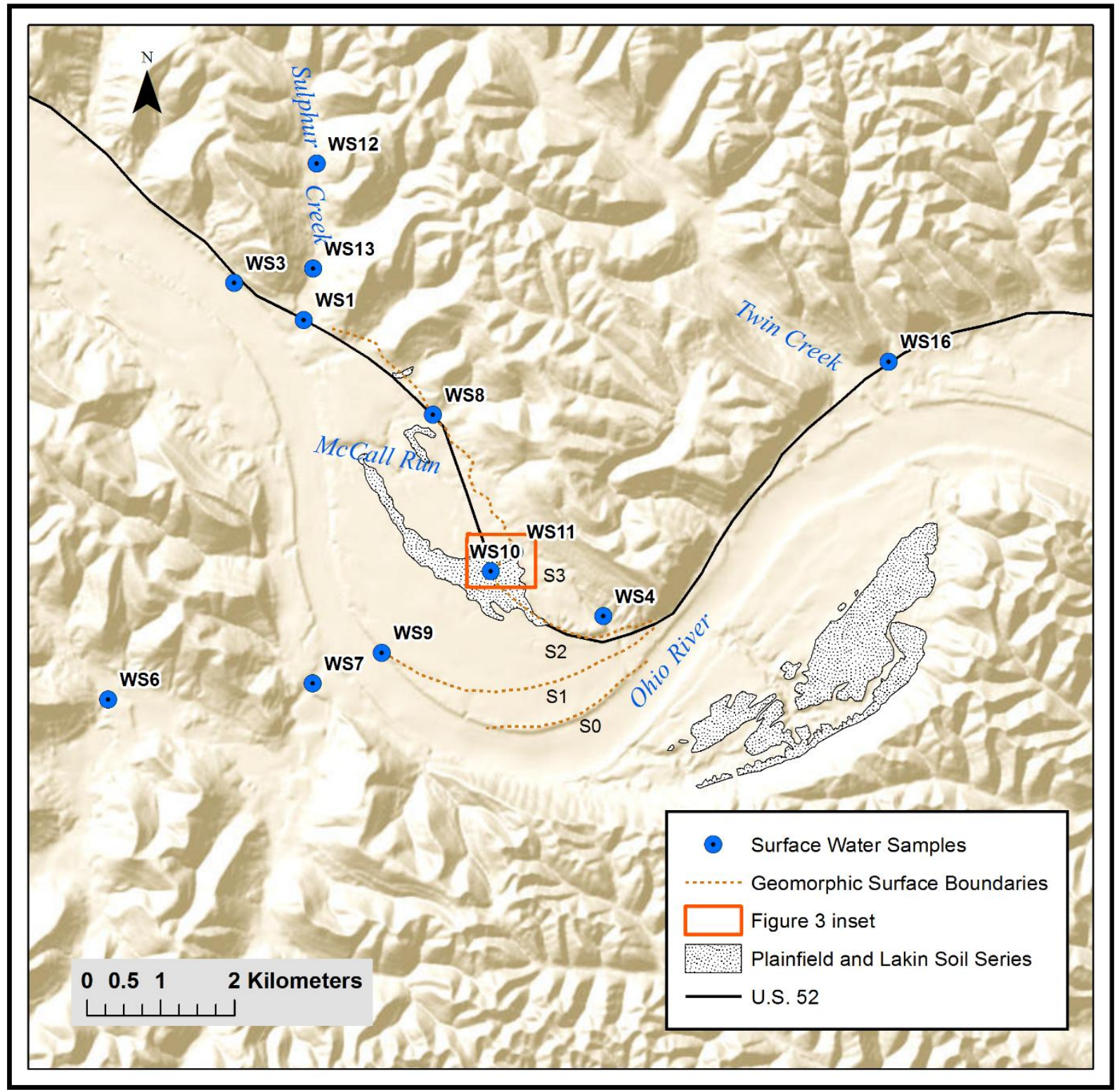

1

Figure 2. Location of surface water samples within the immediate Sandy Springs area. For convenience, Turkey Creek (WS2), located $19.4 \mathrm{~km}$ to the east, is not illustrated. Plainfield and Lakin Series symbol maps the distribution of sandy soils and dunes. 


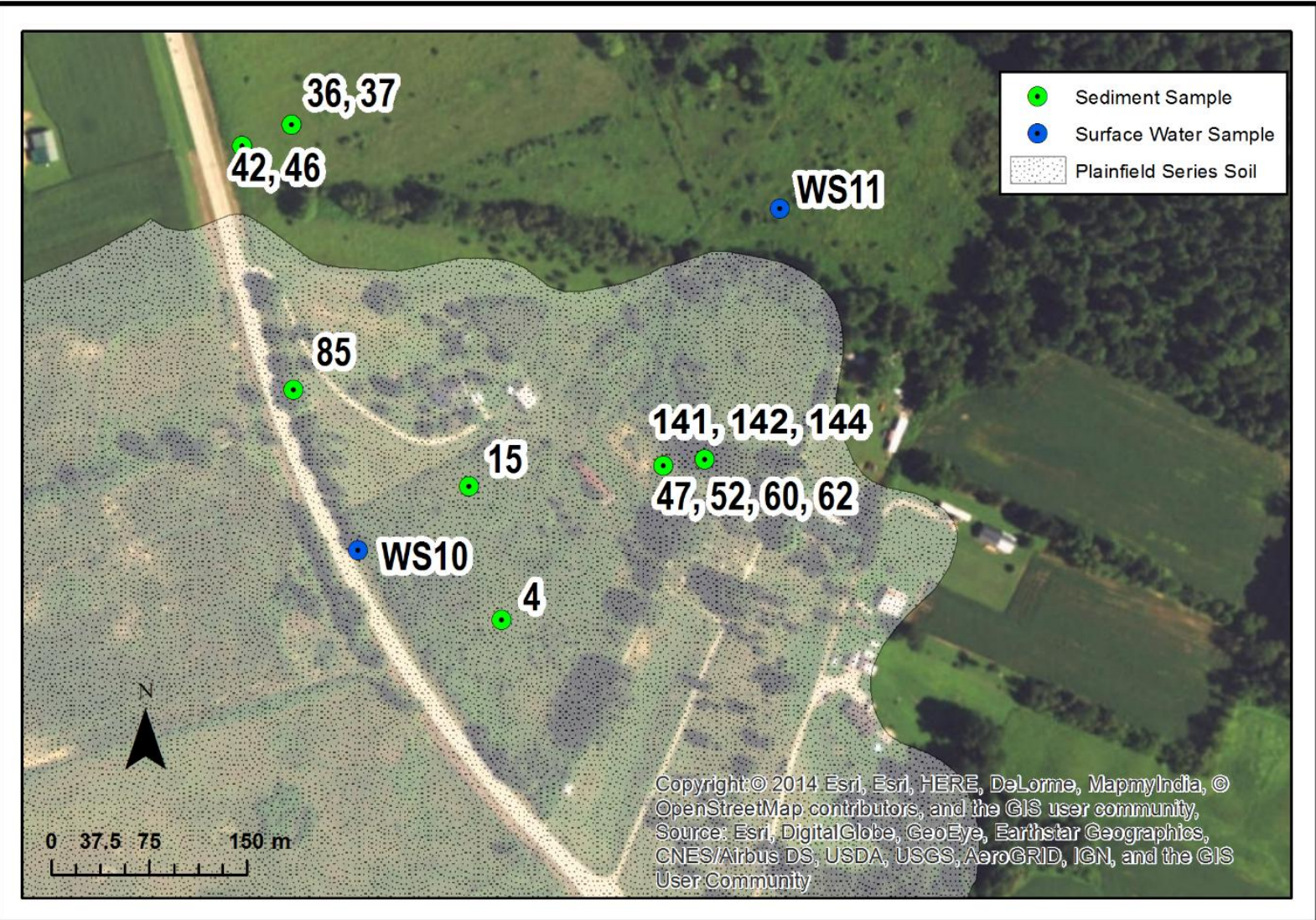

1

Figure 3. Location of sediment samples in relation to dunes and Plainfield Series Soil in Sandy 3 Springs. See Figure 2 for figure location. 
collected from a dry gully north of the Sandy Springs Cemetery where a second intermittent seep is reported to exist by local resident Carmel Taylor (141, 142, and 144). Sulphur Creek, a bedrock channel reach just west of Sandy Springs, was sampled at three locations (WS1, WS12, and WS13), each underlain by a different bedrock geology (Estill Shale, Pebbles Dolomite, and Ohio Shale, respectively), to determine if conductivity is constrained by lithology.

Seven sediment samples from sand dunes and a sand sheet were tested (4, 15, 47, 52, 60, 62, and 85 ) to evaluate Cunningham's claim of saline springs being recharged from clay seams within, or immediately below, dunes (as cited in Seeman et al., 1994:79). All dune samples are from soils classified as Plainfield Series (Lucht \& Brown, 1994) (Table 2). Four additional sediment samples $(36,37,42$, and 46), classified as Sciotoville Series soils, were collected from a finegrained alluvium of an unnamed tributary immediate west of the dunes to determine the potential that saline seeps emerge from below dune settings. To determine if $\mathrm{pH}$ values of dune sediments vary significantly from non-dune contexts, an additional 78 fine-grained sediment samples from alluvial contexts were tested. Alluvial samples were collected across the Sandy Springs meanderbelt area as part of a related geomorphological project currently being conducted by the author.

Finally, three non-Sandy Springs surface water samples were collected for comparative purposes. These samples include Big Bone Creek (WS15) in Union, Kentucky, an outlet stream of an active saline spring (WS14) adjacent to Big Bone Creek, and Little Salt Creek (Scioto Saline) in Jackson, Ohio (WS5). As mentioned previously, these locations are known to have been the focus of historical salt works and the presence of elevated water salinity is well established at each location.

\subsection{Salinity}

Electrical conductivity was measured for all water and sediment samples to determine dissolved ionic concentration, or simply salinity (Walton, 1989). A Hanna Instruments HI9033 multi-range conductivity meter was used to measure water samples and a Mettler Toledo $\mathrm{pH}$ and conductivity meter was used for sediment samples. Water samples were measured directly whereas sediment samples were measured from a saturated paste consisting of 2:1 deionized water to sediment ( $5 \mathrm{~g}$ of sediment: $10 \mathrm{ml}$ of deionized water) mixture. Pastes were agitated and allowed to stand overnight before measurement. Salinity for sediment and water samples initially were calculated as microSiemens $(\mu \mathrm{S} / \mathrm{cm})$ compensated to $25^{\circ} \mathrm{C}$. To facilitate inter-study comparability, $\mu \mathrm{S} / \mathrm{cm}$ units were divided by a standard correction factor of 1.56 to convert to estimated ppm TDS (Walton, 1989).

\section{3. $p H$}

A Mettler Toledo $\mathrm{pH}$ and conductivity meter was used to determine $\mathrm{pH}$ measurements for sediment samples. Measurements were taken on a saturated paste consisting of 1:1 deionized water to sediment ( $5 \mathrm{~g}$ of sediment: $5 \mathrm{ml}$ of deionized water) mixture. Prior to measurement, pastes were agitated and allowed to stand for $\sim 1$ hour. 


\begin{tabular}{|c|c|c|c|c|c|}
\hline Context & Code & USDA-NRCS Soil Type & Soil Profile $^{1}$ & $\begin{array}{l}\text { Sample } \\
\text { Depth (m) }\end{array}$ & $\begin{array}{l}\text { Sample } \\
\text { Texture }\end{array}$ \\
\hline Dune, Cut-bank 1/1a & 52 & $\begin{array}{l}\text { Plainfield sand, } 3 \text { to } 8 \\
\text { percent slopes }\end{array}$ & $\begin{array}{l}\mathrm{A}-\mathrm{Bw}-2 \mathrm{Bw}-3 \mathrm{Bw}-3 \mathrm{C}-4 \mathrm{C}- \\
5 \mathrm{C}-6 \mathrm{C}\end{array}$ & 1.40 & sand \\
\hline Dune, Cut-bank 1/1a & 47 & $\begin{array}{l}\text { Plainfield sand, } 3 \text { to } 8 \\
\text { percent slopes }\end{array}$ & $\begin{array}{l}\text { A-Bw-2Bw-3Bw-3C-4C- } \\
5 \mathrm{C}-6 \mathrm{C}\end{array}$ & 1.60 & sand \\
\hline Dune, Cut-bank 1/1a & 60 & $\begin{array}{l}\text { Plainfield sand, } 3 \text { to } 8 \\
\text { percent slopes }\end{array}$ & $\begin{array}{l}\text { A-Bw-2Bw-3Bw-3C-4C- } \\
5 \mathrm{C}-6 \mathrm{C}\end{array}$ & 3.45 & sand \\
\hline Dune, Cut-bank 1/1a & 62 & $\begin{array}{l}\text { Plainfield sand, } 3 \text { to } 8 \\
\text { percent slopes }\end{array}$ & $\begin{array}{l}\text { A-Bw-2Bw-3Bw-3C-4C- } \\
5 \mathrm{C}-6 \mathrm{C}\end{array}$ & 4.10 & sand \\
\hline Sand sheet, Shovel Test 5 & 4 & $\begin{array}{l}\text { Plainfield sand, } 3 \text { to } 8 \\
\text { percent slopes }\end{array}$ & A-Ap-Bw-C & 1.60 & sand \\
\hline Sand sheet, Shovel Test 24 & 15 & $\begin{array}{l}\text { Plainfield sand, } 3 \text { to } 8 \\
\text { percent slopes }\end{array}$ & A-Ap-Bw-C & 1.65 & silty sand \\
\hline Dune, Cut-bank 2/2b & 85 & $\begin{array}{l}\text { Plainfield sand, } 3 \text { to } 8 \\
\text { percent slopes }\end{array}$ & A-C1-2C2-2C3-3C4-3C5g & 3.10 & silty sand \\
\hline $\begin{array}{l}\text { Dune/Suspected seep area, } \\
\text { Giddings Probe } 6\end{array}$ & 141 & $\begin{array}{l}\text { Plainfield sand, } 3 \text { to } 8 \\
\text { percent slopes }\end{array}$ & $\begin{array}{l}\text { AC-Bw-C1-C2-2AC'- } \\
2 C^{\prime} 1-2 C^{\prime} 2\end{array}$ & 0.43 & silty sand \\
\hline $\begin{array}{l}\text { Dune/Suspected seep area, } \\
\text { Giddings Probe } 6\end{array}$ & 142 & $\begin{array}{l}\text { Plainfield sand, } 3 \text { to } 8 \\
\text { percent slopes }\end{array}$ & $\begin{array}{l}\text { AC-Bw-C1-C2-2AC'- } \\
2 C^{\prime} 1-2 C^{\prime} 2\end{array}$ & 1.52 & silty sand \\
\hline $\begin{array}{l}\text { Dune/Suspected seep area, } \\
\text { Giddings Probe } 6\end{array}$ & 144 & $\begin{array}{l}\text { Plainfield sand, } 3 \text { to } 8 \\
\text { percent slopes }\end{array}$ & $\begin{array}{l}\text { AC-Bw-C1-C2-2AC'- } \\
2 C^{\prime} 1-2 C^{\prime} 2\end{array}$ & 3.00 & sand \\
\hline $\begin{array}{l}\text { Tributary Alluvium, Shovel } \\
\text { Test } 61\end{array}$ & 37 & $\begin{array}{l}\text { Sciotoville silt loam, } 1 \text { to } \\
6 \text { percent slopes }\end{array}$ & Ap-Bt & 1.14 & sandy mud \\
\hline $\begin{array}{l}\text { Tributary Alluvium, Shovel } \\
\text { Test } 61\end{array}$ & 36 & $\begin{array}{l}\text { Sciotoville silt loam, } 1 \text { to } \\
6 \text { percent slopes }\end{array}$ & Ap-Bt & 1.40 & mud \\
\hline $\begin{array}{l}\text { Tributary Alluvium, Shovel } \\
\text { Test } 58\end{array}$ & 42 & $\begin{array}{l}\text { Sciotoville silt loam, } 1 \text { to } \\
6 \text { percent slopes }\end{array}$ & A-Ap-Bt-BC & 0.95 & sandy mud \\
\hline $\begin{array}{l}\text { Tributary Alluvium, Shovel } \\
\text { Test } 58\end{array}$ & 46 & $\begin{array}{l}\text { Sciotoville silt loam, } 1 \text { to } \\
6 \text { percent slopes }\end{array}$ & A-Ap-Bt-BC & 1.10 & sandy mud \\
\hline
\end{tabular}

2 Bold marks soil horizon from which sediment sample was collected

4 Table 2. Description of soil types and profiles for sediment samples. 


\section{Results}

\subsection{Review of geological literature}

Regional bedrock geology suggests a low potential for saline springs in the area of Sandy Springs. Upper units of the Silurian Salina Group, thought to be the primary source of Ohio brines and saline waters (Carlson, 1991:11-12; Hansen, 1983, 1995; Phalen, 1919:68) are absent in southwestern Ohio in the immediate vicinity of Sandy Springs (Hull, 1990). Furthermore, regional hydrological flow gradients are not conducive to the discharge of hypersaline springs in southwestern Ohio since downward flow occurs in the western part of the state and upward flow and discharge occur in the eastern section (Hansen, 1995:2). This pattern led Hansen (1995:2) to state that "salt springs, at which connate water (brine) is discharged, appear to be confined to eastern Ohio." Also, mapped geologic faults which could provide efficient pathways for deepseated saline waters are absent within $32 \mathrm{~km}$ of Sandy Springs (see Figure 1).

Although the geologic literature suggests that Ohio saline springs are constrained by the distribution of evaporitic rock units, several of northern Kentucky's most prominent licks - Big Bone Lick, Upper and Lower Blue Licks, and Mays Lick - are not underlain by Salina Group formations (Potter, 2007:25). This absence indicates a potential alternate salt source for at least some Ohio Valley saline springs. The source of many of these northern Kentucky licks remains uncertain, but evidence from Big Bone Lick suggests connate water in permeable Middle Cambrian Mount Simon Sandstone or Middle Ordovician St. Peter Sandstone as a primary source (Tankersley, 2007; see also Tankersley et al., 2015). Geochemical analysis of Big Bone Lick groundwater produced $\mathrm{Na}: \mathrm{Cl}$ and $\mathrm{Na}: \mathrm{Br}$ ratios suggestive of Cambrian through Silurian connate water (McCartney et al., 2005). Since Big Bone Lick is situated on the western downward limb of the Cincinnati arch and appears to have an Illinois Basin source based on geochemical analysis (McCartney et al., 2005), it likely is hydrologically unrelated to saline water east of the Cincinnati arch axis, including potential springs at Sandy Springs.

Similar to Sandy Springs, Mays Lick, and the Upper and Lower Blue Licks, are situated on the eastern limb of the Cincinnati arch and likely are subject to similar deep hydrological flow patterns. Unlike Sandy Springs, however, these licks are directly underlain by Ordovician rocks and are located within $1 \mathrm{~km}$ of mapped geologic faults (see Figure 1). The presence of faults may account for why saline springs occur at places such as Mays Lick and the Upper and Lower Blue Licks, but not in other settings underlain by similar bedrock stratigraphy.

\subsection{Review of historical literature}

The historical literature (e.g., Bownocker, 1906; Brown, 1999; Evans \& Stivers, 1900; Hansen, 1983, 1995; Hildreth, 1838; Jakle, 1969; Stout et al., 1932; Stout et al., 1943; Phalen, 1919; Wilcox, 1970) is silent regarding the presence of salt licks, salt works, or buffalo traces in the immediate vicinity of Sandy Springs. It is worth mentioning that two long-term Adams County residents and avid hunters, Carmel Taylor and Ferrel Whisman, both informed the author in 2015 that they were unaware of any salt licks at Sandy Springs. Mr. Taylor even remembers, as a child, drinking 'fresh' water straight from the active seep tested for this study (WS10). 
Given that a substantial eighteenth through nineteenth century buffalo trace - Alanant-owamiowee - crossed the Ohio River near present-day Maysville, Kentucky (Jakle, 1969:690691) (see Figure 1), a lack of known trail systems connecting Sandy Springs to regional licks is noteworthy. The lack of documented animal trails also may, at least partially, contradict the suggestion that Sandy Springs was located along a migratory animal route that served to funnel game into the valley bottomlands (Cunningham, 1973; Gramly \& Funk, 1990:16; Seeman \& Prufer, 1982:157). Although mapped buffalo traces are a relatively recent phenomenon tied to the late Holocene eastern expansion of modern bison (Rostlund, 1960), Smith (1990a:244) has argued that these networks likely are a good analogue for a similar trail system used by Pleistocene herbivores.

Although no mention of saline springs or historical salt works, was identified at Sandy Springs proper, Seeman et al. (1994:79) correctly note that Vanceburg, Kentucky, immediately across the Ohio River, possessed a commercial nineteenth century salt works referred to as the Ohio Salt Lick (Cramer, 1814:107; Jakle, 1969:699). An early visitor to the salt work, Andrew Ellicott, mentioned a natural salt spring located in a creek bed "about one mile from the river in the state of Kentucky" (Ellicott, 1803:14). Ellicott provides little additional information regarding this salt spring and it is uncertain if it represents the same location as the commercial Ohio Salt Lick. Collins and Collins (1877:467) describe the Ohio Salt Lick as containing "two salt wells, three hundred feet deep...from which this part of the state was formerly supplied with salt." The fact that wells were excavated to a depth of 300 feet may indicate that saline concentrations were comparatively weak at the surface, especially if compared to other prolific licks such as Big Bone Lick. Morris and Pierce (1967) also state that some water wells in the Vanceburg area are known to produce sulfate and iron-concentrated waters, but only at depths where Ohio Shale bedrock has been penetrated. Collectively, the Vanceburg literature suggests the presence of at least one natural salt lick within $\sim 1.6 \mathrm{~km}$ from the Ohio River and Sandy Springs.

\subsection{Salinity}

The results of electrical conductivity testing within $20 \mathrm{~km}$ of Sandy Springs indicate low ionic concentrations in regional water sources (Table 3). Surface water samples range between 48.72 and $319 \mathrm{ppm}$, with an average of $185 \mathrm{ppm}$. These samples are well under the <1000 ppm fresh water upper limit established by the USDA (Glasser et al., 2007:35). The two Ohio River samples yielded the highest (319 ppm, WS9), and third highest (310, WS3), concentrations which likely are elevated due to modern anthropogenic inputs. If Ohio River samples are removed, tributary streams average only 161 ppm with Salt Lick Creek (WS7) in Vanceburg, Kentucky, having the highest concentration at $317 \mathrm{ppm}$. Sample WS10, an active seep that emerges from the sand sheet in Sandy Springs yields the freshest water at $48.7 \mathrm{ppm}$.

Although the sample size is small, evidence suggests that lithology weakly influences water salinity at Sandy Springs. Samples underlain by Peebles Dolomite $(\mathrm{n}=6)$ average $123 \mathrm{ppm}$; whereas samples underlain by Estill Shale $(n=3)$ and Ohio Shale $(n=4)$ average slightly higher concentrations at $263 \mathrm{ppm}$ and $219 \mathrm{ppm}$, respectively. As mentioned, some area water wells excavated into Ohio Shale bedrock possess elevated TDS concentrations (Morris \& Pierce, 1967). All salinity readings in this study, however, would be classified as "fresh" according to USDA. 


\begin{tabular}{|c|c|c|c|c|c|c|}
\hline Sample Site & Code & $\begin{array}{c}\text { Distance } \\
\text { to } \\
\text { Sandy } \\
\text { Springs } \\
\text { (km) } \\
\end{array}$ & Surficial Geology & $\begin{array}{l}\text { Month and } \\
\text { Year } \\
\text { Collected }\end{array}$ & $\begin{array}{l}\text { ppm } \\
\text { TDS }\end{array}$ & pH \\
\hline \multicolumn{7}{|l|}{ Surface Water Samples } \\
\hline $\begin{array}{l}\text { Unnamed tributary next } \\
\text { to dunes }\end{array}$ & WS11 & 0.0 & $\begin{array}{l}\text { Alluvium over Peebles Dolomite } \\
\text { (Silurian) }\end{array}$ & May, 2016 & 197 & na \\
\hline Sand sheet seep & WS10 & 0.0 & $\begin{array}{l}\text { Alluvium over Peebles Dolomite } \\
\text { (Silurian) }\end{array}$ & October, 2015 & 48.7 & na \\
\hline McCall Run & WS4 & 1.0 & Peebles Dolomite (Silurian) & October, 2015 & 114 & na \\
\hline Ohio River & WS9 & 1.5 & Bedload over Estill Shale (Silurian) & October, 2015 & 319 & na \\
\hline Gilpen Run Creek & WS8 & 2.0 & Peebles Dolomite (Silurian) & October, 2015 & 137 & na \\
\hline Salt Lick Creek & WS7 & 2.4 & Bedload over Ohio Shale (Devonian) & October, 2015 & 317 & na \\
\hline Sulphur Creek & WS1 & 3.5 & Estill Shale (Silurian) & October, 2015 & 159 & na \\
\hline Sulphur Creek & WS13 & 3.9 & Ohio Shale (Devonian) & August, 2016 & 158 & na \\
\hline Ohio River & WS3 & 4.3 & Bedload over Estill Shale (Silurian) & October, 2015 & 310 & na \\
\hline Salt Lick Creek & WS6 & 4.4 & Bedload over Ohio Shale (Devonian) & October, 2015 & 238 & na \\
\hline Upper Twin Creek & WS16 & 4.5 & Peebles Dolomite (Silurian) & August, 2016 & 99.4 & na \\
\hline Sulphur Creek & WS12 & 4.9 & Peebles Dolomite (Silurian) & August, 2016 & 143 & na \\
\hline Turkey Creek & WS2 & 19.4 & Ohio Shale (Devonian) & October, 2015 & 164 & na \\
\hline $\begin{array}{c}\text { Little Salt Creek (Scioto } \\
\text { Saline) } \\
\end{array}$ & WS5 & 74.7 & $\begin{array}{l}\text { Bedload over Maxville Limestone } \\
\text { (Mississippian) }\end{array}$ & October, 2015 & 330 & na \\
\hline $\begin{array}{l}\text { Salt lick, Big Bone Lick } \\
\text { State Park }\end{array}$ & WS14 & 130.1 & $\begin{array}{c}\text { Alluvium over Kope Shale } \\
\text { (Ordovician) }\end{array}$ & August, 2016 & 7240 & na \\
\hline $\begin{array}{l}\text { Big Bone Creek, Big } \\
\text { Bone Lick State Park }\end{array}$ & WS15 & 130.1 & $\begin{array}{c}\text { Alluvium over Kope Shale } \\
\text { (Ordovician) }\end{array}$ & August, 2016 & 321 & na \\
\hline \multicolumn{7}{|c|}{ Sediment Samples } \\
\hline $\begin{array}{l}\text { Dune, 3C horizon, } 1.4 \mathrm{~m} \\
\text { bs, sand }\end{array}$ & 52 & 0.0 & $\begin{array}{l}\text { Alluvium over Peebles Dolomite } \\
\text { (Silurian) }\end{array}$ & $\begin{array}{l}\text { September, } \\
2015\end{array}$ & 8.39 & 5.78 \\
\hline $\begin{array}{c}\text { Dune, } 4 \mathrm{C} \text { horizon, } 1.6 \mathrm{~m} \\
\text { bs, sand }\end{array}$ & 47 & 0.0 & $\begin{array}{l}\text { Alluvium over Peebles Dolomite } \\
\text { (Silurian) }\end{array}$ & $\begin{array}{l}\text { September, } \\
2015 \\
\end{array}$ & 8.68 & 5.50 \\
\hline $\begin{array}{c}\text { Dune, } 6 \mathrm{C} \text { horizon, } 3.45 \\
\mathrm{~m} \text { bs, sand }\end{array}$ & 60 & 0.0 & $\begin{array}{l}\text { Alluvium over Peebles Dolomite } \\
\text { (Silurian) }\end{array}$ & October, 2015 & 5.52 & 4.98 \\
\hline $\begin{array}{c}\text { Dune, 6C horizon, } 4.1 \mathrm{~m} \\
\text { bs, sand }\end{array}$ & 62 & 0.0 & $\begin{array}{l}\text { Alluvium over Peebles Dolomite } \\
\text { (Silurian) }\end{array}$ & $\begin{array}{l}\text { September, } \\
2015\end{array}$ & 11.4 & 4.96 \\
\hline $\begin{array}{l}\text { Sand sheet, C horizon, } \\
1.6 \mathrm{~m} \mathrm{bs} \text {, sand } \\
\end{array}$ & 4 & 0.0 & $\begin{array}{c}\text { Alluvium over Peebles Dolomite } \\
\text { (Silurian) }\end{array}$ & May, 2015 & 9.13 & 5.63 \\
\hline $\begin{array}{l}\text { Sand sheet, C horizon, } \\
1.65 \mathrm{~m} \text { bs, silty sand }\end{array}$ & 15 & 0.0 & $\begin{array}{c}\text { Alluvium over Peebles Dolomite } \\
\text { (Silurian) }\end{array}$ & May, 2015 & 39.0 & 5.62 \\
\hline $\begin{array}{c}\text { Dune, 3C5g horizon, } 3.1 \\
\text { m bs, silty sand }\end{array}$ & 85 & 0.0 & $\begin{array}{c}\text { Alluvium over Peebles Dolomite } \\
\text { (Silurian) }\end{array}$ & $\begin{array}{l}\text { November, } \\
2015 \\
\end{array}$ & 14.9 & 5.04 \\
\hline $\begin{array}{c}\text { Dune/Seep area, AC } \\
\text { horizon, } 0.43 \mathrm{~m} \text { bs, silty } \\
\text { sand } \\
\end{array}$ & 141 & 0.0 & $\begin{array}{l}\text { Alluvium over Peebles Dolomite } \\
\text { (Silurian) }\end{array}$ & $\begin{array}{l}\text { November, } \\
2015\end{array}$ & 21.2 & 5.16 \\
\hline $\begin{array}{c}\text { Dune/Seep area, Bw } \\
\text { horizon, } 1.52 \mathrm{~m} \text { bs, silty } \\
\text { sand }\end{array}$ & 142 & 0.0 & $\begin{array}{l}\text { Alluvium over Peebles Dolomite } \\
\text { (Silurian) }\end{array}$ & $\begin{array}{l}\text { November, } \\
2015\end{array}$ & 6.80 & 5.86 \\
\hline $\begin{array}{c}\text { Dune/Seep area, C } \\
\text { horizon, } 3 \mathrm{~m} \text { bs, sand }\end{array}$ & 144 & 0.0 & $\begin{array}{l}\text { Alluvium over Peebles Dolomite } \\
\text { (Silurian) }\end{array}$ & $\begin{array}{l}\text { November, } \\
2015\end{array}$ & 8.39 & 6.24 \\
\hline $\begin{array}{c}\text { Tributary Alluvium, Bt } \\
\text { horizon, } 1.14 \mathrm{~m} \mathrm{bs}, \\
\text { Sandy Mud }\end{array}$ & 37 & 0.0 & $\begin{array}{l}\text { Alluvium over Peebles Dolomite } \\
\text { (Silurian) }\end{array}$ & $\begin{array}{l}\text { September, } \\
2015\end{array}$ & 8.10 & 5.49 \\
\hline $\begin{array}{l}\text { Tributary Alluvium, Bt } \\
\text { horizon, } 1.4 \mathrm{~m} \text { bs, Mud }\end{array}$ & 36 & 0.0 & $\begin{array}{l}\text { Alluvium over Peebles Dolomite } \\
\text { (Silurian) }\end{array}$ & $\begin{array}{l}\text { September, } \\
2015\end{array}$ & 16.1 & 5.32 \\
\hline
\end{tabular}




\begin{tabular}{|c|c|c|c|c|c|c|}
\hline $\begin{array}{c}\text { Tributary Alluvium, Bt } \\
\text { horizon, } 0.95 \mathrm{~m} \mathrm{bs}, \\
\text { Sandy Mud }\end{array}$ & 42 & 0.0 & $\begin{array}{l}\text { Alluvium over Peebles Dolomite } \\
\text { (Silurian) }\end{array}$ & $\begin{array}{l}\text { September, } \\
2015\end{array}$ & 20.4 & 5.11 \\
\hline $\begin{array}{l}\text { Tributary Alluvium, BC } \\
\text { horizon, } 1.1 \mathrm{~m} \text { bs, Sandy } \\
\text { Mud }\end{array}$ & 46 & 0.0 & $\begin{array}{l}\text { Alluvium over Peebles Dolomite } \\
\text { (Silurian) }\end{array}$ & $\begin{array}{l}\text { September, } \\
2015\end{array}$ & 19.2 & 5.17 \\
\hline
\end{tabular}

1

2 Table 3. Results of electrical conductivity and $\mathrm{pH}$ analysis for surface water and sediment 3 samples 
Samples from surface water sources acclaimed to possess concentrated saline waters, including Little Salt Creek (Scioto Saline) and Big Bone Creek (Big Bone Lick State Park), yielded slightly higher concentrations than Sandy Springs sources at 330 and $321 \mathrm{ppm}$, respectively. Although more concentrated, these waters still are classified as fresh water. Sample WS13, which was measured just a few meters downstream of an active saline spring producing a strong sulfur odor at Big Bone Lick, yielded a brackish water reading of 7,240 ppm, 2000 percent greater than any Sandy Springs sample (Table 3). The Big Bone Lick reading reported here is similar to one reported from the Lower Blue Lick where water salinity measured 10,296 ppm in 1850 (Hopkins, 1966:2). Taken together, brackish water readings from licks at Big Bone Lick and Lower Blue Lick better align with expectations of a spring sufficiently saline as to attract large numbers of sodium-deprived animals.

\section{4. $p H$}

Responses of soil $\mathrm{pH}$ to cation and anion enrichment is complex and related to myriad factors of water chemistry, climate and precipitation trends, and salt composition. For example, most researchers report increasing $\mathrm{pH}$ levels in the presence of sodium chlorides, gypsum, sodium sulfates, and bicarbonates (e.g., Gupta et al., 1989; Miller et al., 1993; Schaetzl \& Anderson, 2005:427-430), although at least one study reports a pH decrease in the presence of calcium carbonates (e.g., Al-Busaidi \& Cookson, 2003). Though soluble salts would not be expected to accumulate in the upper reaches of permeable sediments such as sand, at least in the humid eastern U.S., sediments located below the wetting front or proximal to supersaturated saline groundwater may result in mineral precipitation and associated soil salinization which would alter soil pH, presumably raising it (Schaetzl \& Anderson, 2005:427-430).

The 14 samples from contexts within, or adjacent, to dunes and the sand sheet yielded $\mathrm{pH}$ values in the slightly acidic range between 4.96 and 6.24, with an average of 5.40 (Table 2). When compared to a larger sample of 78 sediment samples from non-dune, alluvial, contexts across Sandy Springs, no statistical difference was identified as these sediments produced a $\mathrm{pH}$ range between 4.35 and 7.98, with an average of $5.40(t=0.0048 ; p=0.996)$. These $\mathrm{pH}$ ranges are well within reported county-wide values for local Plainfield and Sciotoville Soil Series (Lucht \& Brown, 1994:186-190).

\subsection{Discussion and Conclusion}

As illustrated in recent treatises on eastern U.S. Paleoindian archaeology, it is increasingly clear that many traditional models of Paleoindian chronology, settlement, economics, land-use behavior, and subsistence, require careful reevaluation (e.g., Anderson, 2013; Anderson et al., 2015; Ellis, 2011; Eren et al., 2015; Holliday \& Miller, 2014; Meltzer \& Holliday, 2010; Speth et al., 2013; Waters \& Stafford, 2007). Many current models rely heavily on data from sites that, in truth, are poorly documented or understood. This reliance has resulted in calls for increased efforts to reinvestigate classic eastern U.S. Paleoindian sites (see Gingerich, 2013a). Reinvestigation of sites such as Shoop (Carr et al., 2013), Bull Brook (Robinson et al., 2009; Robinson \& Ort, 2013), Plenge (Gingerich, 2013b), and Shawnee-Minisink (Gingerich, 2013c) has provided new insights into intra-site organization and in many cases corrected enduring inaccuracies. 
The results of electrical conductivity testing of surface water and sediment samples, $\mathrm{pH}$ testing of sediment samples, and review of relevant geological and historical literature, fail to confirm Cunningham's often cited claim of high salinity for area groundwater and streams at Sandy Springs. Geologically, Sandy Springs is not underlain by shallow evaporite rock units nor are significant geologic faults mapped for the area. TDS values of tested water samples within $20 \mathrm{~km}$ of Sandy Springs yielded concentrations between 48.7 and 320 ppm, all well below USDA's brackish water threshold of 1,000 ppm (Glasser et al., 2007:35). These values also are far below reported values for known salt licks at Big Bone Lick (7,240 ppm, this study) and Lower Blue Licks (10,296 ppm; Hopkins, 1966:2). Finally, no mention of commercial salt wells or animal trails such as buffalo traces was located in the literature for Adams County, Ohio.

Although this study failed to identify evidence of surficial saline waters at Sandy Springs proper, historical evidence suggests that a natural saline spring was situated approximately $1.6 \mathrm{~km}$ south of the Ohio River near the modern town of Vanceburg, Kentucky (Ellicot, 1803:43). It is possible that historic accounts of this spring may be the source of Cunningham's initial claim of hypersaline waters. The absence of known animal trails or buffalo traces connecting this lick to other documented licks such as Lower Blue Licks or Big Bone Lick (see Figure 1), fail to suggest a spring of sufficient size or salinity to attract substantial numbers of game or subsequent human predators. Indeed, the simple fact that Paleoindian material is concentrated at Sandy Springs, Ohio, and not $\sim 2 \mathrm{~km}$ away at Vanceburg, Kentucky, suggests that Ellicot's reported lick was only a minor resource during the late Pleistocene.

The possible absence of saline springs from Sandy Springs severely undermines a key component in the narrative that has surrounded the Paleoindian occupation of the site since Cunningham's 1973 article. As initially claimed, the presence of saline waters and subsequent concentration of sodium-deprived game helped explain why Sandy Springs was repeatedly, and intensively, occupied by Paleoindians despite being located in an unglaciated landscape far removed from high-quality bedded chert sources (Lepper \& Meltzer, 1991). Without the presence of saline springs, it is difficult to offer a reason as to why hunted game would repeatedly concentrate at Sandy Springs in the first place. Accordingly, the abundance of projectile points at Sandy Springs, although clearly indicative of a population heavily invested in hunting strategies (Seeman et al., 1994:83), does not necessarily equate to a site that functioned as a hunting station. In this view, the presence of projectile points at Sandy Springs may be incidental, perhaps simply reflecting the high archaeological visibility of chert artifacts upon a persistently reoccupied late Pleistocene landscape. The possibility that additional resources, including non-economic ones (e.g., see Speth et al., 2013), may have attracted late Pleistocene groups to Sandy Springs is considered in the remainder of this article.

Aside from hunting, I offer two broad hypotheses that may account for the persistent occupation of Sandy Springs by Paleoindians. First, Sandy Springs is characterized by a remnant sand prairie ecosystem which contains a range of rare plant and animal species (Ohio Department of Natural Resources Natural Areas \& Preserves, 2016). Assuming that this ecosystem dates to the late Pleistocene in some form, it is possible that this setting contained desirable resources otherwise difficult to obtain in the upper Ohio River Valley. One possible plant resource that could have been targeted by Paleoindians is the eastern prickly pear cactus (Opuntia humifusa) 
which was observed to be a prolific colonizer of sand dunes at Sandy Springs. This succulent is known to possess various pharmaceutical benefits including use as an anti-inflammatory agent, and also produces edible foliage and fruits (Abella \& Jaeger, 2004). O. humifusa was used by various historical Native American tribes for both medicinal and subsistence reasons (Gilmore, 1919; Moerman, 1988) and plant remains have been found within archaeological middens at several eastern U.S. sites (e.g., McAvoy \& Harrison, 2012; Mosely, 1931).

A second potential reason as to why Sandy Springs was persistently occupied may be related to the initial efforts of wayfinding, trail establishment, and cognitive map development that accompanies early attempts at landscape learning by colonizing populations (Golledge, 2003; Kelly, 2003; Meltzer, 2003). As part of the landscape learning process, preliterate huntergatherer societies are known to focus initially on landforms that are visually unique, easy to identify, and easy to relocate. Through naming and myth creation, such localities become imbued with social meaning which aids in mnemonic learning of new landscapes (see Kelly, 2003:4548). Places also may attain significance if they are the scene of dramatic events, especially ones that may reinforce important social norms or practices (e.g., Biesele, 1993:55-56). Miller (2016:712) also suggests that distinctive locations would have been ideal for periodic aggregation of dispersed Paleoindian populations in the southeast as a way to build, and maintain, social relationships. It also has long been suggested that bedded chert outcrops would have similarly attracted eastern U.S. Paleoindians where socially important information, goods, and perhaps people (i.e., marriage partners), could be exchanged among otherwise dispersed communities (e.g., Eren et al., 2015; Ellis, 2011; Gardner, 1977; Smallwood, 2012).

I suggest that Sandy Springs may have served in a similar manner for late Pleistocene groups early in the landscape learning process. Although Sandy Springs is not located close to bedded chert outcrops, the hummocky landscape contains large sand dunes and, coupled with the presence of a xeric biome, the site would have been visually distinctive and easy to describe to others. The visibility of raised dunes may have been enhanced further by an open, grassy, savannah-like environment that, based on pollen data, may have persisted on this broad meanderbelt during this time (see Purtill, 2012:42-43).

Relatedly, Sandy Springs may have gained prominence among late Pleistocene groups by being strategically located along an early northeast-to-southwest trail system. Seeman \& Prufer (1982:157) initially discussed this possibility and suggested that Sandy Springs may have been situated along a route connecting two areas of high Paleoindian site densities: Tennessee and Cumberland drainages and the upper Ohio River drainage (Anderson, 1990, 1995; Anderson et al., 2015). The documentation of at least 15 Cumberland points from Sandy Springs (Seeman et al., 1994) implies a southerly connection since this point style is geographically restricted to the southeast (Tune, 2106). According to Tune (2016:311), Sandy Springs is located near the northern-most extension of the Cumberland point geographic distribution (Figure 4) and he suggests that the site may have functioned as an aggregation location for seasonally dispersed groups (Tune 2016:314) (Figure 4).

If long-distance travels, perhaps as part of seasonal logistical forays (e.g., Boulanger et al., 2014; Eren and Redmond, 2011; Ellis, 2011), were occurring between the Tennessee-Cumberland and upper Ohio drainages, one potential route would have been along the Cumberland Escarpment 


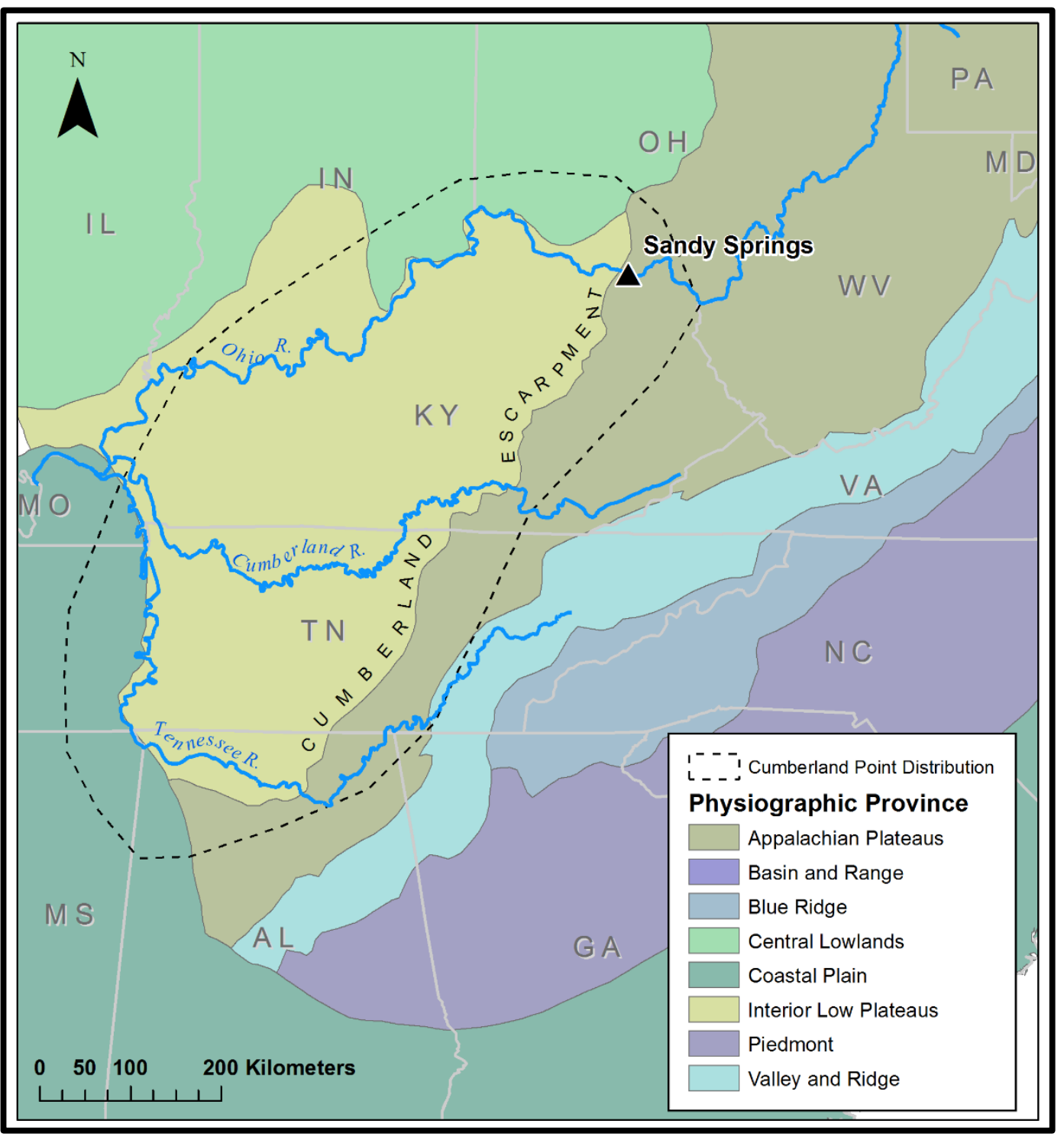

Figure 4. Location of Sandy Springs in relation to the Cumberland Escarpment and its position at 3 the northern distribution of Cumberland projectile points (following Tune, 2016:311). 
which separates the low-relief Interior Low Plateaus from the elevated, deeply dissected, Appalachian Plateaus Provinces (Fenneman \& Johnson, 1946) (Figure 4). This southwest-tonortheast trending escarpment is represented by a series of knobs and ridges that range in relief from $\sim 125 \mathrm{~m}$ in northeastern Kentucky to as high as $600 \mathrm{~m}$ in southern Tennessee, northern Alabama, and northwestern Georgia (Simpson \& Florea, 2009:71). The high-relief terrain would have provided a prominent landform to guide travel and several researchers have indicated that physiographic boundary areas were especially attractive to Paleoindians (e.g., Miller, 2016:710; Tune, 2016:311). Significantly, groups following the western escarpment edge northward from the Tennessee and Cumberland drainages would arrive at the upper Ohio River within $10 \mathrm{~km}$ of Sandy Springs (Figure 4) where a natural ford could facilitate river crossing (see Seeman et al, 1994:79). The presence of Paleoindian points manufactured from Upper Mercer chert at Sandy Springs (Seeman et al., 1994:81), which crops out to the northeast in east-central Ohio (Stout \& Schoenlab, 1945:39-60), also indicates a northeasterly connection for the area as well. It is possible that Sandy Springs was strategically positioned along a north-south trail system that, once established early in Paleoindian times, became incorporated into a cognitive map of the region and continued to be used throughout the Paleoindian period. This interpretation fits well with current views of eastern U.S. Paleoindian societies being socially interconnected over broad distances, especially with regards to aspects of chert acquisition (e.g., Boulanger et al., 2015; Ellis, 2011; Eren and Redmond, 2011; Eren et al., 2015; Speth et al., 2013). It also may suggest that Sandy Springs, and perhaps other upper Ohio River Paleoindian sites, had occupants more aligned culturally with southern Paleoindian societies than northern ones, at least during the period of Cumberland point manufacture (12,800-12,100 cal yr BP; Tune, 2016:312).

Finally, a word of caution is offered regarding the potential role of salt licks and late Pleistocene hunters. Even at renowned Pleistocene salt licks such as Big Bone Lick in Kentucky and Saltville in Virginia, the possibility that Paleoindian material and Pleistocene megafauna are contemporary or directly associated is tenuous and poorly supported (McCary, 1951:11; Shaler, 1893:180; Tankersley, 1996:28; see also Grayson \& Meltzer, 2002). This fact, coupled with the results of this study, reemphasizes the importance of critically reevaluating data from many of the sites we already know since they often form the foundation for many current models of eastern U.S. Paleoindian behavior.

\section{Acknowledgements}

Funding from the 2016 NASA West Virginia Space Grant Consortium Graduate Research Fellowship and the Eberly College of Arts and Sciences, Doctoral Student Research Program, West Virginia University, supported various aspects of this research. Several individuals provided project assistance including J. Steven Kite and Joseph Donovan of West Virginia University; Mark Seeman of Kent State University; Steve Baker of USDA-NRCS; Mike Angle, Frank Fugitt, and Nathan Erber of the Ohio Geological Survey; James Thompson of West Virginia University; Chris Bedel of the Edge of Appalachia Preserve System; and Nancy Stranahan of the Arc of Appalachia. The following also assisted in field and laboratory efforts: Francesca Basil; Andrew Braun; Nick Dadamo; Sara DeAloia; Lena Fox, Nancy Gostic; Zach Haidar; Heather Jewel; Matt Koerner; Miles Reed; Emily Swaney; and Joey Zampayo. Special thanks go to the Adams, Rutledge, and Whisman families for providing property access. Finally, review comments provided by two anonymous reviewers improved the quality of this article. 


\section{References}

Abella, S.R., \& Jaeger, J.F. (2004). Ecology and Eastern Prickly Pear cactus (Opuntia Humifusa) in Oak Openings Preserve, Northwestern Ohio. The Michigan Botanist, 43, 1-11.

Al-Busaidi, A. S., \& Cookson, P. (2003). Salinity-pH relationships in calcareous soils. Agricultural and Marine Sciences, 8(1), 41-46.

Anderson, D. G. (1990). The Paleoindian colonization of eastern North America. Research in Economic Anthropology Supplement, 5, 163-216.

Anderson, D. G. (1995). Paleoindian interaction networks in the Eastern Woodlands. In M. S. Nassaney, \& K. E. Sassaman (Eds.), Native American interaction: Multiscalar analyses and interpretations in the Eastern Woodlands (pp. 1-26). Knoxville: University of Tennessee Press.

Anderson, D. G. (2013). Paleoindian archaeology in eastern North America: Current approaches and future directions. In J. A. M. Gingerich (Ed.), In the eastern fluted point tradition (pp. 371-404). Salt Lake City: The University of Utah Press.

Anderson, D. G., Smallwood, A. M., \& Miller, D. S. (2015). Pleistocene human settlement in the southeastern United States: Current evidence and future directions. Paleoamerica, 1(1), 751.

Anderson, D. G., \& Gillam, J. C. (2000). Paleoindian colonization of the Americas: Implications from an examination of physiography, demography, and artifact distribution. American Antiquity, 65(1), 43-66.

Baranoski, M. T. (2013). Structure contour map on the Precambrian unconformity surface in Ohio and related basement features (version 2.0) (Division of Geological Survey Map PG23 ed.). Columbus: Ohio Department of Natural Resources.

Biesele, M. (1993). Women like meat: The folklore and foraging ideology of the Kalahari Ju/hoan. Bloomington: Indiana University Press.

Boisvert, R. A. (1984). Kentucky salt licks: A preservation planning perspective. Lexington: Office of State Archaeology, University of Kentucky.

Botkin, D. B., Jordan, P. A., Dominski, A. S., Lowendorf, H. S., \& Hutchinson, G. E. (1973). Sodium dynamics in a northern ecosystem. Proceedings of the National Academy of Sciences of the United States of America, 70(10), 2745-2748.

Boulanger, M. T., Buchanan, B., O'Brien, M. J., Redmond, B. G., Glascock, M. D., \& Eren, M. I. (2015). Neutron activation analysis of 12,900-year-old stone artifacts confirms $450-510 \mathrm{~km}$ Clovis tool-stone acquisition at Paleo Crossing (33ME274), northeast Ohio, USA. Journal of Archaeological Science, 53, 550-558. 
Bownocker, J. A. (1906). Salt deposits and the salt industry in Ohio. Springfield: Springfield Publishing Company.

Brockman, C. S. (2006). Physiographic regions of Ohio. Division of Geological Survey, Department of Natural Resources. Columbus: State of Ohio.

Broster, J. B., Norton, M. R., Miller, D. S., Tune, J. W., \& Baker, J. D. (2013). Tennessee's Paleoindian record: The Cumberland and lower Tennessee River watersheds. In J. A. M. Gingerich (Ed.), In the eastern fluted point tradition (pp. 299-314). Salt Lake City: The University of Utah Press.

Brown, I. W. (1999). Salt manufacture and trade from the perspective of Avery Island, Louisiana. Midcontinental Journal of Archaeology, 24(2), 113-151.

Brown, I. W. (2010). The archaeology of salt springs in the Eastern Woodlands of the United States. In S. Li, \& L. von Falkenhausen (Eds.), Salt archaeology in China: Global comparative perspectives (vol. 2) (pp. 375-409). Beijing: Science Press.

Cannon, M. D., \& Meltzer, D. J. (2004). Early Paleoindian foraging: Examining the faunal evidence for large mammal specialization and regional variability in prey choice. Quaternary Science Reviews, 23(18-19), 1955-1987.

Cannon, M. D., \& Meltzer, D. J. (2008). Explaining variability in early Paleoindian foraging. Quaternary International, 191(1), 5-17.

Carlson, E. H. (1991). Minerals of Ohio. Columbus: State of Ohio, Department of Natural Resources, Division of Geological Survey.

Carr, K. W., Adovasio, J. M., \& Vento, F. J. (2013). A report on the 2008 field investigations at the Shoop site (36DA20). In J. A. M. Gingerich (Ed.), In the eastern fluted point tradition (pp. 75-103). Salt Lake City: The University of Utah Press.

Collins, L., \& Collins, R. H. (1877). History of Kentucky. Louisville: Richard H. Collins.

Cramer, Z. (1814). The navigator. Pittsburgh: Cramer, Spear and Eichbaum.

Cunningham, R. M. (1973). Paleo-hunters along the Ohio River. Archaeology of Eastern North America, 1(1), 118-126.

Dethier, V. G. (1977). The taste of salt. American Scientist, 65(6), 744-751.

Dincauze, D. F. (1993). Fluted points in the eastern forests. In O. Soffer, \& N. D. Praslov (Eds.), From Kostenki to Clovis (pp. 279-292). New York: Springer.

Ellicott, A. (1803). The journal of Andrew Ellicott. Philadelphia: Ayer Publishing. 
Ellis, C. J. (2011). Measuring Paleoindian range mobility and land-use in the Great Lakes/Northeast. Journal of Anthropological Archaeology, 30(3), 385-401.

Eren, M. I., \& Desjardine, A. (2015). Flaked stone tools of Pleistocene colonizers: Overshot flaking at the Red Wing site, Ontario. In T. A. Jennings, \& A. M. Smallwood (Eds.), Clovis: On the edge of a new understanding (pp. 109-120). College Station: Texas A\&M Press.

Eren, M. I., Buchanan, B., \& O'Brien, M. J. (2015). Social learning and technological evolution during the Clovis colonization of the New World. Journal of Human Evolution, 80, 159170 .

Eren, M. I., \& Redmond, B. G. (2011). Clovis blades at Paleo Crossing (33ME274), Ohio. Midcontinental Journal of Archaeology, 36(2), 173-194.

Eren, M. I., Vanderlaan, S., \& Holland, J. D. (2011). Overshot flaking at the Arc site, Genesee County, New York: Examining the Clovis-Gainey connection . The Open Anthropology Journal, 4, 40-52.

Evans, N. W., \& Stivers, E. B. (1900). A history of Adams County, Ohio. West Union: Emmons B. Stivers.

Fenneman, N., \& Johnson, D. (1946). Physiographic divisions of the conterminous U.S. Washington, D.C.: US Geological Survey.

Fraser, D., \& Reardon, E. (1980). Attraction of wild ungulates to mineral-rich springs in central Canada. Holarctic Ecology, 3(1), 36-39.

Gardner, W. M. (1977). Flint Run Paleoindian Complex and its implications for eastern North American prehistory. Annals of the New York Academy of Sciences, 288(1), 257-263.

Gilmore, M. R. (1919). Uses of plants by the Indians of the Missouri River region, Washington, D.C.: 33rd Annual Report of the Bureau of American Ethnology.

Gingerich, J. A. M. (Ed.). (2013a). In the eastern fluted point tradition. Salt Lake City: The University of Utah Press.

Gingerich, J. A. M. (2013b). Fifty years of discovery at Plenge: Rethinking the importance of New Jersey's largest Paleoindian site. In J. A. M. Gingerich (Ed.), In the eastern fluted point tradition (pp. 121-147). Salt Lake City: The University of Utah Press.

Gingerich, J. A. M. (2013c). Revisiting Shawnee-Minisink. In J. A. M. Gingerich (Ed.), In the eastern fluted point tradition (pp. 218-258). Salt Lake City: The University of Utah Press.

Glasser, S., Gauthier-Warinner, J., Keely, J., Gurrieri, J., Tucci, P., Summers, P., \& McCormack, K. (2007). Technical guide to managing ground water resources. Washington, D.C.: United States Department of Agriculture. 
Golledge, R. G. (2003). Human wayfinding and cognitive maps. In M. Rockman, \& J. Steele (Eds.), Colonization of unfamiliar landscapes: The archaeology of adaptation (pp. 25-43). London: Routledge.

Gramly, R. M., \& Funk, R. E. (1990). What is known and not known about the human occupation of the Northeastern United States until 10,000 BP. Archaeology of Eastern North America, 18, 5-31.

Grayson, D. K., \& Meltzer, D. J. (2002). Clovis hunting and large mammal extinction: A critical review of the evidence. Journal of World Prehistory, 16(4), 313-359.

Gupta, R. K., Singh, R. R., \& Abrol, I. P. (1989). Influence of simultaneous changes in sodicity and $\mathrm{pH}$ on the hydraulic conductivity of an alkali soil under rice culture. Soil Science, 147(1), 28-33.

Hansen, M. C. (1983). Ohio's salt industry. Ohio Geology Newsletter, Division of Geological Survey, (Fall), 1-6.

Hansen, M. C. (1995). The Scioto Saline - Ohio's early salt industry. GeoFacts No. 7. Columbus: Ohio Department of Natural Resources, Division of Geological Survey.

Hellgren, E. C., \& Pitts, W. J. (1997). Sodium economy in white-tailed deer (Odocoileus virginianus). Physiological and Biochemical Zoology, 70(5), 547-555.

Hem, J. D. (1985). Study and interpretation of the chemical characteristics of natural water (Third ed.). Alexandria: U.S. Geological Survey Water-Supply Paper 2254.

Hildreth, S. P. (1838). Salt springs. Ohio Division of Geological Survey, First Annual Report, 54-62.

Hillel, D. (2013). Fundamentals of soil physics. New York: Academic Press.

Holliday, V. T., \& Miller, D. S. (2014). The Clovis landscape. In K. E. Graf, C. V. Ketron \& M. R. Waters (Eds.), Paleoamerican odyssey (pp. 221-245). College Station: Texas A\&M University Press.

Hopkins, H. T. (1966). The fresh-saline water interface in Kentucky (10th ed.). Lexington: Kentucky Geological Survey.

Hull, D. N. (1990). Generalized column of bedrock units in Ohio. Columbus: Ohio Department of Natural Resources, Division of Geological Survey.

Imlay, G. (1793). A topographical description of the western territory of North America. London: William Jones.

Jakle, J. A. (1969). Salt on the Ohio Valley frontier, 1770-1820. Annals of the Association of American Geographers, 59(4), 687-709. 
Kelly, R. L. (2003). Colonization of new land by hunter-gatherers. In M. Rockman, \& J. Steele (Eds.), Colonization of unfamiliar landscapes: The archaeology of adaptation (pp. 44-58). London: Routledge.

Kelly, R. L., \& Todd, L. C. (1988). Coming into the country: Early Paleoindian hunting and mobility. American Antiquity, 53(2), 231-244.

Kentucky Geological Survey. (May, 2016). Kentucky geological survey geologic map service. Retrieved from http://kgs.uky.edu/kgsmap/kgsgeoserver/viewer.asp

Kreulen, D.A. (1985). Lick use by large herbivores: A review of benefits and banes of soil consumption. Mammal Review, 15, 107-123.

Lepper, B. T. (1986). Early Paleo-indian land use patterns in the central Muskingum River basin, Coshocton County, Ohio. (Unpublished PhD). The Ohio State University, Department of Anthropology, Columbus.

Lepper, B. T., \& Meltzer, D. J. (1991). Late Pleistocene human occupation of the eastern United States. In R. Bonnichsen, \& K. L. Turnmire (Eds.), Clovis: Origins and adaptations (pp. 175-184). Corvallis: Center for the Study of the First Americans, Oregon State University.

Lothrop, J. C., \& Cremeens, D. L. (2010). 33Ms391: A Paleoindian site in southwestern Ohio. Current Research in the Pleistocene, 27, 120-122.

Lucht, T. E., \& Brown, D. L. (1994). Soil survey of Adams County, Ohio. Columbus: United States Department of Agriculture - Soil Conservation Service.

Maggard, G. J., \& Kerri L. Stackelbeck. (2008). Paleoindian period. In D. Pollack (Ed.), The archaeology of Kentucky: An update (volume I) (pp. 73-192). Frankfort: The Kentucky Heritage Council.

McAvoy, W. A., \& Harrison, J. W. (2012). Plant community classification and the flora of Native American shell-middens on the Delmarva Peninsula. Maryland Naturalist, 52, 1-34.

McCartney, D. M., Finney, M. A., \& Maynard, J. B. (2005). Sources of the salt in the Big Bone Lick springs, northern Kentucky. Denver: Geological Society of America.

McCary, B. C. (1951). A workshop site of early man in Dinwiddie County, Virginia. American Antiquity, 17(1), 9-17.

Meltzer, D. J. (2003). Lessons in landscape learning. In M. Rockman, \& J. Steele (Eds.), Colonization of unfamiliar landscapes: The archaeology of adaptation (pp. 222241). London: Routledge Publishing.

Meltzer, D. J., \& Holliday, V. T. (2010). Would North American Paleoindians have noticed Younger Dryas age climate changes? Journal of World Prehistory, 23(1), 1-41. 
Meltzer, D. J., \& Smith, B. D. (1986). Paleoindian and Early Archaic subsistence strategies in eastern North America. In S. Neusius (Ed.), Foraging, collecting and harvesting: Archaicperiod subsistence and settlement in the Eastern Woodlands (pp. 2-31). Carbondale: Center for Archaeological Investigations Occasional Paper.

Miller, J.J., Pawluk, S., \& Beke, G.J. (1993). Soil salinization at a side-hill seep and closed basin in southern Alberta. Canadian Journal of Soil Science, 73, 209-222.

Miller, S.D. (2016). Modeling Clovis Landscape Use and Recovery Bias in the Southeastern United States using the Paleoindian Database of the Americas (PIDBA). American Antiquity, 81(4), 697-716.

Moerman, D. E. (1988). Native American ethnobotany. Portland: Timber Press.

Morris, R. H., \& Pierce, K. L. (1967). Geologic map of the Vanceburg Quadrangle. KentuckyOhio: US Geological Survey Geologic Quadrangle Map GQ-598, Lexington: Kentucky Geological Survey, University of Kentucky.

Moseley, E. L. (1931). Some plants that were probably brought to northern Ohio from the west by Indians. Papers of the Michigan Academy of Sciences, Arts \& Letters, 13, 169-172.

Noelle, H.J. \& Blackwell, W.H. (1972). The Cactaceae in Ohio. Castanea, 37 (2), 119-124.

O'Brien, M. J. (1996). Paradigms of the past: The story of Missouri archaeology. Columbia: University of Missouri Press.

Ohio Department of Natural Resources, Natural Areas \& Preserves. (May, 2016). Rare Plants in Ohio. Retrieved from http://naturepreserves.ohiodnr.gov/rareplants.

Pavey, R. R., Goldthwait, R. P., Brockman, C. S., Hull, D. N., Swinford, E. M., \& Van Horn, R. G. (1999). Quaternary geology of Ohio (Map No. 2 ed.). Columbus: Ohio Division of Geological Survey.

Phalen, W. C. (1919). Salt resources of the United States. Washington, DC: United States Geological Survey.

Potter, P. E. (2007). Exploring the geology of the Cincinnati/Northern Kentucky region (second revised edition) (Series XII ed.). Lexington: Kentucky Geological Survey, University of Kentucky.

Purtill, M. P. (2012). A persistent place: A landscape approach to the prehistoric archaeology of the Greenlee Tract in southern Ohio. Raleigh: Lulu Press, Inc.

Purtill, M. P., \& Kite, J. S. (2015). Midwestern sand dunes, geoarchaeology, and lidar: Preliminary geomorphic landform analysis of the sandy springs Paleoindian site in the upper 
Ohio River Valley. Geological Society of America Abstracts with Programs. Vol. 47, no. 5, p.89, Madison.

Purtill, M. P. (2016). Aeolian and fluvial interaction in the Middle Ohio River Valley: New geomorphic, stratigraphic, and sedimentological evidence from Sandy Springs, Adams County, Ohio. Geological Society of America Abstracts with Programs. Vol. 48, no.75, p.90, Denver.

Ray, C. E., Cooper, B. N., \& Benninghoff, W. S. (1967). Fossil mammals and pollen in a late Pleistocene deposit at Saltville, Virginia. Journal of Paleontology, 41(3):608-622.

Redmond, B. G., \& Tankersley, K. B. (2005). Evidence of early Paleoindian bone modification and use at the Sheriden Cave site (33WY252), Wyandot county, Ohio. American Antiquity, 70(3), 503-526.

Robinson, B. S., \& Ort, J. C. (2013). Spatial organization at Bull Brook. In J. A. M. Gingerich (Ed.), In the eastern fluted point tradition (pp. 104-120). Salt Lake City: The University of Utah Press.

Robinson, B. S., Ort, J. C., Eldridge, W. A., Burke, A. L., \& Pelletier, B. G. (2009). Paleoindian aggregation and social context at Bull Brook. American Antiquity, 74(3), 423-447.

Rolingson, M. A. (1964). Paleo-indian culture in Kentucky: A study based on projectile points. Lexington: University of Kentucky Press.

Rostlund, E. (1960). The geographic range of the historic bison in the southeast. Annals of the Association of American Geographers, 50(4), 395-407.

Schaetzl, R. J., \& Anderson, S. (2005). Soils: Genesis and geomorphology. Cambridge: Cambridge University Press.

Schultz, C. B., Tanner, L. G., Whitmore Jr, F. C., Ray, L. L., \& Crawford, E. C. (1963). Paleontologic investigations at Big Bone Lick State Park, Kentucky: A preliminary report. Science, 142, 1167-1169.

Seeman, M. F., \& Prufer, O. H. (1982). An updated distribution of Ohio fluted points. Midcontinental Journal of Archaeology, 7(2), 155-169.

Seeman, M. F., Summers, G., Dowd, E., \& Morris, L. (1994). Fluted point characteristics at three large sites: The implications for modeling early Paleoindian settlement patterns in Ohio. In W. S. Dancey (Ed.), The first discovery of America: Archaeological evidence of the early inhabitants of the Ohio area (pp. 77-94). Columbus: Ohio Archaeological Council.

Shaler, N. (1893). Antiquity of man in eastern North America. The American Geologist, 11, 180184. 
Simpson, L. C., \& Florea, L. J. (2009). The Cumberland Plateau of eastern Kentucky. In A. N. Palmer, \& M. V. Palmer (Eds.), Caves and karst of America (Volume 1 ed., pp. 70-79). Huntsville: National Speleological Society.

Smallwood, A. (2012). Clovis technology and settlement in the American Southeast: Using biface analysis to evaluate dispersal models. American Antiquity, 77(4), 689-713.

Smith, E. E. (1990a). Paleoindian economy and settlement patterns in the Wyandotte chert source area, unglaciated south-central Indiana. Research in Economic Anthropology Supplement, 5, 217-258.

Smith, E. E. (1990b). Paleo-indian settlement and lithic procurement patterns in the karstic region of southcentral Indiana. (Unpublished Dissertation) Indiana University, Department of Anthropology, Bloomington.

Speth, J. D., Newlander, K., White, A. A., Lemke, A. K., \& Anderson, L. E. (2013). Early Paleoindian big-game hunting in North America: Provisioning or politics? Quaternary International, 285, 111-139.

Stout, W., \& Schoenlaub, R. (1945). The occurrence of flint in Ohio. Columbus: Geological Survey of Ohio.

Stout, W., Lamborn, R.E., Schaaf, D. (1932). Brines of Ohio. Columbus: Geological Survey of Ohio.

Stout, W., Ver Steeg, K., \& Lamb, G. F. (1943). Geology of water in Ohio (a basic report). Columbus: Geological Survey of Ohio.

Surovell, T. A., \& Waguespack, N. M. (2009). Human prey choice in the late Pleistocene and its relation to megafaunal extinctions. In G. Haynes (Ed.), American megafaunal extinctions at the end of the Pleistocene (pp. 77-105). New York: Springer.

Tankersley, K. B. (1985). The potential for early man sites at Big Bone Lick, Kentucky. Tennessee Anthropologist, 10, 27-49.

Tankersley, K. B. (1990). Late Pleistocene lithic exploitation in the Midwest and Midsouth: Indiana, Ohio, and Kentucky. Research in Economic Anthropology Supplement, 5, 259-302.

Tankersley, K. B. (1996). Ice age hunters and gatherers. In R. B. Lewis (Ed.), Kentucky archaeology (pp. 21-38). Lexington: The University of Kentucky Press.

Tankersley, K. B. (1998). Variation in the early Paleoindian economies of late Pleistocene eastern North America. American Antiquity, 63(1), 7-20.

Tankersley, K. B. (2007). Stop 1: Big Bone Lick, Kentucky - late Pleistocene archaeology. In T. S. Dalbey (Ed.), Guidebook no. 11: Geological aspects of key archaeological sites in 
Northern Kentucky and Southern Ohio (pp. 45-49). Columbus: Geological Society of America.

Tankersley, K. B., Waters, M. R., \& Stafford Jr, T. W. (2009). Clovis and the American mastodon at Big Bone Lick, Kentucky. American Antiquity, 74(3), 558-567.

Tankersley, K. B., Murari, M. K., Crowley, B. E., Owen, L. A., Storrs, G. W., \& Mortensen, L. (2015). Quaternary chronostratigraphy and stable isotope paleoecology of Big Bone Lick, Kentucky, USA. Quaternary Research, 83(3), 479-487.

Todd, D. K., \& Mays, L. W. (2005). Groundwater hydrology. Hoboken: John Wiley \& Sons, Inc.

Tune, J. W. (2016). Characterizing Cumberland fluted biface morphology and technological organization. Journal of Archaeological Science, Reports, 6, 310-320.

Vincent, M.A., Gardner, R.L., \& Riley, B.P. (2011). Additions to and interesting records for the Ohio vascular flora (with one new record for Indiana). Phytoneuron, 60, 1-23.

Waguespack, N. M., \& Surovell, T. A. (2003). Clovis hunting strategies, or how to make out on plentiful resources. American Antiquity, 68(2), 333-352.

Walton, N.R.G. (1989). Electrical Conductivity and Total Dissolved Solids - What is their precise relationship? Desalination, 72 (3), 275-292.

Waters, M. R., \& Stafford, T. W. (2007). Redefining the age of Clovis: Implications for the peopling of the Americas. Science, 315(5815), 1122-1126.

Weeks, H. P., \& Kirkpatrick, C. M. (1976). Adaptations of white-tailed deer to naturally occurring sodium deficiencies. The Journal of Wildlife Management, 40(4), 610-625.

Wilcox, F. N. (1970). Ohio Indian trails: A pictorial survey of the Indian trails of Ohio. Kent: Kent State University Press. 